(20) 医器学 Vol 50, No.4 (1980)

○シンポジウム（II）

救急医療と医科器械

司会 東京大救急部 都 築 正 和

\section{II-1．，心肺蘇生に必要な医科器械 一主として酸素代謝の面から一}

大阪大特殊救急部 吉 岡 敏 治

臨床医学が細分化されるにつれて, 各領域の 医科機械の進歩はめざましいものがある. 救急 医療を行なら上で，これら他の医学分野と異な った特異な医科器械を使用するということは比 較的少ないが，その疾病構造から見ても重症度 から見ても救急医療機関ではあらゆる種類の患 者を処置する可能性がある. しかしながら救急 医療機関が各専門領域で現在までに開発された 医科器械を全て備えることは特殊な施設を除い てほとんど不可能である.

そこで今回はわれわれが比較的遭遇する機会 の多い心肺蘇生に際して必要な医科機械につい て, その種類, 使用頻度などを検討し，これを 基礎にして一般開業医に常備すべき救急セット

(A型)，一般病院の院内患者に対処するため の救急七ット (B型), 救急病院外来処置室に 備えるべき救急セット ( $\mathrm{C}$ 型), について考察 する．この中では Gスーツや除細動装置, 自動 心マッサージ機など特殊な医療機器についても 言及したい。

続いて心肺蘇生後の濃厚治療に際して必要な 医療機器やモニタ類, 特にレスピレータ, 心拍 出量計，医用質量分析装置 (Medical Mass Spectrometer）について最近の進歩とその使用 上の問題点を検討する.

\section{II一2. 救急医療における検查システム}

神奈川衛生短大 高原喜八郎

今日，広、医療の分野において，救急医療技 術の進歩とシステム化 はまことに目覚ましい ものがあり，I C UやC C Uなどはいうまでも なく, 急患対策のシステム化はひとり個々の病 院内のプロジェクトのみにとどまらず，広く地 域レベルに㧍ける包括プロジェクトとして検討 されるようになってきた。

医療の現場のニーズによって臨床検査技術が 生まれてきたゆえに，緊急（救急）医療に揖い ても実に多数の緊急検查專用機種を誕生させる にいたった． 1 分間で血液学的検査データを提 供するコールターSをはじめとして，やはり 1 分以内に血糖, $\mathrm{BUN}, \mathrm{Na}, \mathrm{K}, \mathrm{Cl}, \mathrm{Ca}^{+2}$, な どの生化学項目のデータを指示する各種専用分 析計が開発常用され，またビリルビン，血液ガ ス, C P K やアミラーゼなどの酵素 専用分析 計，血中薬剤の緊急流定のシステム化などはこ れらを雄弁に物語るものであろう。

ところでこれらの緊急検查用機種の特徵とし ては，操作がいずれも簡易であって専門の検査 技師でない人々によっても使用できるようにな った点であろら。しかしながら，この大きな利 点にはやはり裹があるのであって, 緊急検査機 器が正しく作動するためには, 定められた保守 管理作業が毎日, および毎週, 専門技師によっ てチェックされていなければならないのであ る.したがって, ここに検査部門と臨床部門が 切実に交流協力する新らしい土俵が生じたこと になる。この新しい土俵の運営にはいろいろの 方式が考えられよう。例えば機器の保守整備の み技師が分担して, その使用は臨床サイドが当 る。検查部内に緊急検査室を設けて24時間体制 で技師がすべてに当る。 あるいは検查部内に緊 急検査室を設けるよりも, 進んで病棟や外来に 技師が出張して臨床チームと共同してベッドサ イドで検査を実施する諸例が検討される。 また 地域的には緊急検査機器を装備した自動車 (動 く緊急検查室）が患家に急行して医師の緊急処 置隹力するシステムも要望されよう。 